\title{
Ovine Tunica Albuginea as Xenograft for Cystoplasty in Rats
}

\begin{abstract}
Natasha Nogueira Ferreira ${ }^{1}$, Cecília Ribeiro Castañon ${ }^{2}$, Fellipe Ferreira Lemos de Medeiros', Fernanda Moreira da Silva ${ }^{3}$, Bruna Scalzilli $^{1}$, Tábata Maués ${ }^{3 *}$, Carla Ferreira Farias Lancetta ${ }^{4}$, Viviane Alexandre Nunes Degani ${ }^{4}$ and Maria de Lourdes Gonçalves Ferreira ${ }^{5}$
\end{abstract}

${ }^{1}$ Postgraduate Program in Clinic and Animal Breeding, Universidade Federal Fluminense, Niterói, RJ, Brazil

${ }^{2}$ Department of Morphology, Universidade Castelo Branco, Rio de Janeiro, RJ, Brazil

${ }^{3}$ Professor, Firmino Mársico Filho Veterinary Teaching Hospital, Universidade Federal

Fluminense, Niterói, RJ, Brazil

${ }^{4}$ Department of Morphology, Universidade Federal Fluminense, Niterói, RJ, Brazil

${ }^{5}$ Department of Clinical Pathology, Universidade Federal Fluminense, Niterói, RJ, Brazil

*Corresponding Author: Tábata Maués, Professor, Firmino Mársico Filho Veterinary

Teaching Hospital, Universidade Federal Fluminense, Niterói, RJ, Brazil.
Received: June 20, 2020

Published: June 30, 2020

(C) All rights are reserved by Natasha

Nogueira Ferreira., et al.

DOI: $10.31080 /$ ASVS.2020.02.0082

\begin{abstract}
The purpose of this study was to prove the conserved ovine tunica albuginea (OTA) as a practicable and adequate biomaterial for bladder scaffolds even as its histopathological cicatrization aspects. The conserved heterologous OTA implant was experimentally used for cystoplasty in 20 Wistar rats. The operated bladder areas of all rats from test $(n=20)$ and simulation $(n=20)$ groups were examined macroscopically and histologically at 7, 14, 2, 8 and 42 postoperative days. Test group animals underwent partial cystectomy followed by cystoplasty with OTA graft application, and simulation group rats to partial cystectomy. There was no mortality in any group, and all animals showed good post-surgery recovery. Bladders histopathological analysis showed that the test group obtained more intensive blood vessels and had the first signs of total regeneration earlier than the simulation group. Our findings pointed that macroscopic and histological results, easiness of surgical technique and graft availability, OTA can be used as an alternative biomaterial graft for bladder wall reconstruction in rats which represent a valuable animal model to comparative studies with the human being and other species.

Keywords: Biomaterials; Bladder; Cystoplasty; Scaffold; Tissue Engineering
\end{abstract}

\section{Introduction}

Bladder diseases such as cancer, traumatisms, congenital and chronic injuries can make a reconstructive surgery needed [1,2]. A potential strategy to minimize possible postoperative complications is tissue engineering, a good promise for bladder repair and reconstruction $[3,4]$. In this context, techniques have been proposed such as the use of epithelial cells and biomaterials of collagen [5-7].

Biomaterials used for bladder reconstruction must have fast degradation since one of the main related complications is the formation of urolithiasis by a foreign body. Therefore, a scaffold with a mechanical force that facilitates the regeneration process and amplifies bladder capacity and complacency is required [8]. In this regard, some studies had good results using tunica albuginea biomaterial as tissue engineering [9-13]. The tunica albuginea is a thick capsule of connective tissue, composed of two layers of collagen bundles $[14,15]$.

\section{Aim of the Study}

Therefore, the aim of this study was to prove the conserved ovine tunica albuginea (OTA) as a practicable and adequate biomaterial for bladder scaffolds even as its histopathological cicatrization aspects. 


\section{Materials and Methods}

This experiment was approved by the Committee on Ethics in the Use of Animals of Universidade Federal Fluminense with the number 955/17 in accordance with the welfare standards of animals use.

The OTA fragment was collected by the open orchiectomy technique of a healthy Santa Inês sheep. After this procedure, a section was made in the largest axis of the testis, where the epididymis is attached to the tunica albuginea, thus finding a point of cleavage, and releasing the parenchyma of the tunica. Washing was then performed with a $0.9 \%$ sterile physiological solution. The extracted tunica albuginea was conserved in a container with $300 \mathrm{ml}$ of sterile $98 \%$ glycerin solution. It was stored at room temperature (not above $35^{\circ} \mathrm{C}$ ) for at least 60 days to guarantee immunogenic attenuation as well as its antimicrobial effect.

A total of 40 four-month-old male Wistar rats (Rattus novergicus albinus) from Animal Center Laboratory of Universidade Federal Fluminense were selected. They were kept in individual boxes with sawdust bed, controlled temperature $\left(22 \pm 2^{\circ} \mathrm{C}\right)$ and luminosity conditions (12 hours light-dark cycles), receiving drinkable water and food ad libitum.

A Test (T) and a Simulation (S) group were created with 20 animals each, further subdivided into 8 subgroups - T7, T14, T28, T42, and S7, S14, S28 and S42 respectively according to euthanasia period at postoperative day 7, 14, 28 and 42, containing five animals each as shown in table 1 . The difference between $\mathrm{T}$ and $\mathrm{S}$ group was OTA graft placement in T group rats cystoplasty.

\begin{tabular}{|c|c|c|c|c|}
\hline \multicolumn{2}{|c|}{ Nomenclature } & \multirow{2}{*}{$\begin{array}{c}\text { Xenograft } \\
\text { implantation }\end{array}$} & \multirow{2}{*}{$\begin{array}{l}\text { Euthanasia post- } \\
\text { operative day }\end{array}$} & \multirow{2}{*}{$n$} \\
\hline Group & Subgroup & & & \\
\hline \multirow[t]{4}{*}{$\mathrm{T}$} & $\mathrm{T} 7$ & \multirow[t]{4}{*}{ Yes } & 7 & 5 \\
\hline & T14 & & 14 & 5 \\
\hline & $\mathrm{T} 28$ & & 28 & 5 \\
\hline & $\mathrm{T} 42$ & & 42 & 5 \\
\hline \multirow[t]{4}{*}{$S$} & S7 & \multirow[t]{4}{*}{ No } & 7 & 5 \\
\hline & S14 & & 14 & 5 \\
\hline & $\mathrm{S} 28$ & & 28 & 5 \\
\hline & S42 & & 42 & 5 \\
\hline \multicolumn{4}{|c|}{ Total of animals } & 40 \\
\hline
\end{tabular}

Table 1: Wistar rats assigned to Test (T) and Simulation (S) groups and subsequently into subgroups named according to euthanasia post-surgery day 7, 14, 28 and 42 .
The OTA fragment was rehydrated in a $0.9 \%$ sterile physiological solution at least 30 minutes before manipulation, so it could return to its properties.

Briefly, animals were anesthetized using ketamine $(75 \mathrm{mg} / \mathrm{kg})$ and midazolam (10 mg/kg) and tramadol ( $4 \mathrm{mg} / \mathrm{kg})$ combined by intraperitoneal injection, then shaved and antisepsis (1\% chlorhexidine digluconate and alcohol) of the operative field was performed. A low $1.5 \mathrm{~cm}$ midline laparotomy incision was made, and underlying tissue was dissected, including rectal muscle and peritoneum to expose the bladder (Figure 1A) which was emptied with a 30-gauge hypodermic needle attached to a $1 \mathrm{ml}$ syringe (Figure $1 \mathrm{~B}$ ). Then, two seromuscular manipulation points were fixed in both bladder laterals and the partial cystectomy was finally made, withdrawing one-third of bladder diameter with scissors (Figure 1C). The S group had bladder closed with 6-0 polydioxanone absorbable simple continuous suture pattern. Otherwise, a square piece of the OTA scaffold was implanted to the $\mathrm{T}$ group bladder site using a simple continuous suture pattern with 6-0 polydioxanone thread (Figure 1D). After cystorrhaphy, the integrity of closure test by filling the bladder with sterile $0.9 \% \mathrm{NaCl}$ solution was performed to verify possible extravasation points in both groups. After, the omentalization of cystorrhaphy sites was made in $\mathrm{T}$ and $\mathrm{S}$ groups, followed by laparorrhaphy and skin enclosure with simple pattern suture (in absorbable monofilament 3-0 thread). The two groups were assessed for seven days after surgery, receiving topic chlorhexidine spray-on surgical wound (every 24 hours), enrofloxacin $(5 \mathrm{mg} / \mathrm{kg}$ SC every 24 hours), ketoprofen (10 mg/kg SC every 24 hours) and dipyrone (100 mg/kg SC every 24 hours). Animals where evaluated whole postoperative period considering behavior and clinical aspects such as general condition, appetite, activity, surgical wound, defecation, and urination.

At 7,14, 28, and 42 post-surgery days, five animals from each group were euthanized by isoflurane overdose. A macroscopic analysis was performed during the necropsy. Bladder and annexes were collected and preserved in a $10 \%$ buffered formaldehyde solution for 48 hours to until histological processing. Urinary vesicle fragments excised and fixed were embedded in paraffin tissue blocks. Sections $(5 \mu \mathrm{m})$ were cut, stained with hematoxylin and eosin (HE) and then evaluated under a light microscope as described by Tolosa., et al. [16]. The slides were assessed by the same observer with the following parameters: inflammatory infiltrate and its constitution, neovascularization, and graft integration to bladder tissue. These characteristics were analyzed by comparison and graduated in absent $(-)$, low $(+)$, moderate $(++)$, and high (+++) levels. 


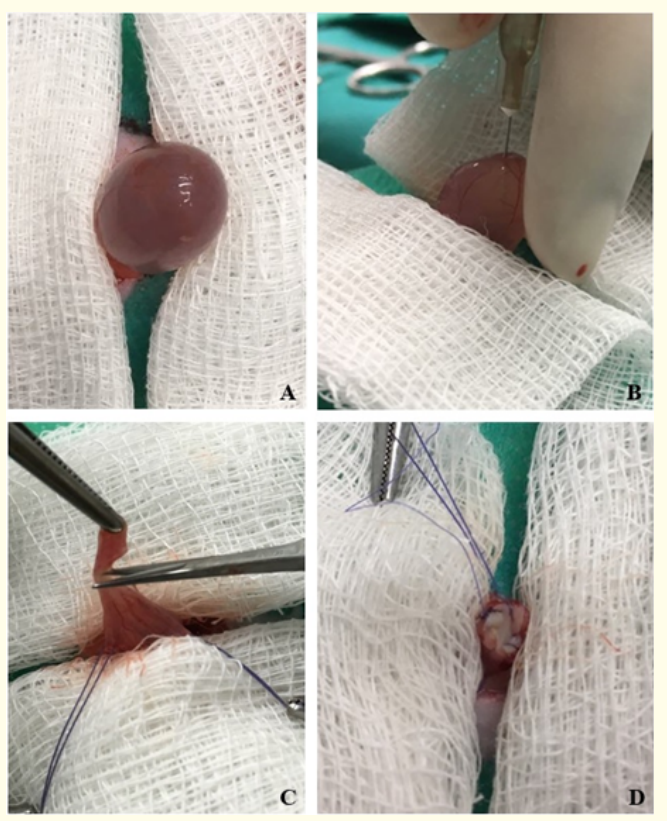

Figure 1: T group surgical procedure of cystoplasty with ovine albugenous tunic as xenograft in Wistar rat. Sequence: (A) Bladder exposure; (B) Cystocentesis; (C) Cistectomy; and (D) OTA xenograft implantation in bladder.

\section{Results and Discussion}

All 40 animals had an uneventful anesthetic return to be reported with maintenance of habitual behavior and appetite, with no deaths after the procedures. Albrecht., et al. [17] also reported similar results, but different to this $50 \%$ mortality of animals was recorded by Pokrywczynska., et al. [18] in rats underwent synthetic membrane cystoplasty. Iijima., et al. [19] reported $42 \%$ of deaths using human amniotic membrane xenograft in cystoplasty in mice. Zhou., et al. [20] reported only two deaths linked to urine leakage and consequently uroperitoneum following bladder augmentation surgery in rats.

Pinto Filho., et al. [21] reported good recovery of surgical wound with no local sensitivity, no hyperthermia, or suture dehiscence in animals. During necropsy, no signs of infection or graft rejection were recorded indicating good application of surgical technique and adequate use of biomaterial as graft. Zhou., et al. [20] observed one death in the control group and one in the test group due to infection secondary to extravasation of urine into the abdominal cavity. Nevertheless, no suture dehiscence at the graft site was noted in any experimental animal. Five animals $(12.5 \%, n=5 / 40)$, in- cluding three rats from $\mathrm{S}$ group and two from the T group, showed granuloma formation at cystoplasty site. Wongsetthachai., et al. [22] also reported granulomatous reaction around suture thread in dogs underwent autologous tunica vaginalis bladder graft. Zhou., et al. [20] observed good incorporation of the chitosan scaffold seeded into stem cells in rats' bladder, aiming to improve urinary vesicle regeneration. It also confirms the results of Albrecht., et al. [17] in the incorporation of porcine pericardium membrane into rabbit cystoplasty, becoming almost indistinguishable from the bladder wall after 14 and 21 postoperative days.

It is noteworthy that during necropsy, crystals, mucus and/or calculus were present in 30 animals $(75 \%, n=30 / 40), 15$ of which were from $S$ group $(75 \%, \mathrm{n}=15 / 20)$ and 15 from $\mathrm{T}$ group $(75 \%, \mathrm{n}=$ 15/20). Similarly, Zhao., et al. [23] also reported calculi and crystals in animals underwent cystotomy, concluding that uroliths development is common with the use of biodegradable materials in reconstructive cystoplasty in rats. Kosan., et al. [24] compared three types of suture: polyglactin 910, chromium catgut and polydioxanone in bladder suture. The last one was the only group where urolith formation was not seen. This finding was different from the current study, in which the uroliths formations were equally divided between the $S$ and $T$ groups, both sutured with polydioxanone absorbable threads, suggesting no exclusively correlation between calculi and OTA graft.

S group animals showed good postoperative recovery and cicatrization, obtaining urothelization and complete layers reorganization at 42 post-surgery days. Similarly, it was also reported by Moraes., et al. [13] in the $\mathrm{S}$ group in addition to a longer delay in the reorganization of smooth muscle tissue, linking this finding to the lack of a scaffold for cell migration when compared to the porcine tunica albuginea $\mathrm{T}$ group. The main histopathological findings in both $\mathrm{T}$ and $\mathrm{S}$ groups were depicted in table 2 .

The T7 subgroup $(100 \%, n=5 / 5)$ showed moderate inflammatory infiltrate at graft periphery, initial urothelial formation as well as serous and muscular layers regeneration (Figure 2A). All $\mathrm{T} 14$ animals $(100 \%, \mathrm{n}=5 / 5)$ showed an intense inflammatory reaction spreading over and fragmenting the tunica albuginea, complete urothelization and serous, and muscular layers organization (Figure 2C). This was compatible with Albrecht., et al. [17] findings, where animals showed acute inflammation at 7 days post-surgery, evolving to chronic at 14 days, ranging from absent epithelization in 7 days to complete only at 21 days. In the same study, neoangio- 


\begin{tabular}{|l|c|c|c|c|}
\hline \multicolumn{2}{|c|}{ Nomenclature } & Inflamma- & $\begin{array}{c}\text { Neovascu- } \\
\text { larization }\end{array}$ & $\begin{array}{c}\text { Graft integra- } \\
\text { tion }\end{array}$ \\
\hline \multirow{4}{*}{ Group } & Subgroup & tion & ++ & - \\
\hline \multirow{4}{*}{$\mathrm{T}$} & $\mathrm{T} 7$ & ++ & ++ & + \\
\cline { 2 - 5 } & $\mathrm{T} 14$ & +++ & +++ & ++ \\
\cline { 2 - 5 } & $\mathrm{T} 28$ & ++ & +++ & +++ \\
\cline { 2 - 5 } & $\mathrm{T} 42$ & ++ & +++ & Not applicable \\
\hline S & $\mathrm{S} 7$ & + & + & Not applicable \\
\cline { 2 - 5 } & $\mathrm{S} 14$ & ++ & ++ & Not applicable \\
\cline { 2 - 5 } & $\mathrm{S} 28$ & + & + & Not applicable \\
\cline { 2 - 5 } & $\mathrm{S} 42$ & - & ++ & \\
\hline
\end{tabular}

Table 2: Evaluation of degree of inflammation, neovascularization, and graft absorption in animals of group $\mathrm{T}$ and $\mathrm{S}$ at postoperative days $7,14,28$, and 42 .

Absent (-); Low (+); Moderate $(++)$; High $(+++)$ levels.

genesis was found to be increased up to the $14^{\text {th }}$ day and remained until day 21. Moraes., et al. [13] also found clear regeneration of the grafted areas whereas that used porcine tunica albuginea in rats cystoplasty.

Figures 2A and 2C showed bladder microscopic findings in animals from subgroups T7 and T14, at post-surgery days 7 and 14 in animals who had OTA grafted. Meanwhile, figures 2B and 2D showed histopathological features in rats bladder from subgroups S7 and S14, at postoperative days 7 and 14.

In T28 subgroup, moderate inflammatory reaction in OTA graft and fully regenerated serosa layer were seen $(100 \%, n=5 / 5)$. Besides, the muscular layer showed initiated implant overlap, being already seen one animal $(20 \%, n=1 / 5)$ with total absorption of the grafting material (Figure $3 \mathrm{~A}$ ). The biomaterial quality had great importance in the regeneration induction of the bladder layers, mainly of the urothelium. However, the greatest difficulty was in the reorganization of the smooth muscle [23], which explains the faster regeneration of the serosa layer and urothelial.

Finally, in the T42 rats subgroup, all layers were completely regenerated, with an intact urothelium $(100 \%, n=5 / 5)$. Correspondingly, urothelial differentiation was observed at day 56 after bladder augmentation with four-layer porcine small intestinal submucosa in rats [25]. All animals from the present study showed defined lamina propria and tunica albuginea almost completely absorbed by an inflammatory infiltrate (Figure 3C), different from that seen by Zhou., et al. [20], who only found complete formation of the smooth muscle after 8 weeks of the experiment. Wong- setthachai., et al. [22] observed complete coverage of the replaced tissue, forming mucosa at 42 postoperative days. Using a bioengineered three-dimensional bladder patch comprising porous scaffolds and multilayered adipose-derived stem cell sheets in the rat model, Wang., et al. [26] also reported regeneration of urothelium, smooth muscle and blood vessels. The epithelization of the bladder wall was preceded by an inflammatory reaction, as noted in the current study.

Figures 3A and 3C showed bladder microscopic visualization in animals from subgroups T7 and T14, at post-surgery days 21 and 42 in animals who had OTA. Meantime, figures 3B and 3D showed histopathological features in rats bladder from subgroups S7 and S14, at postoperative days 21 and 42 .

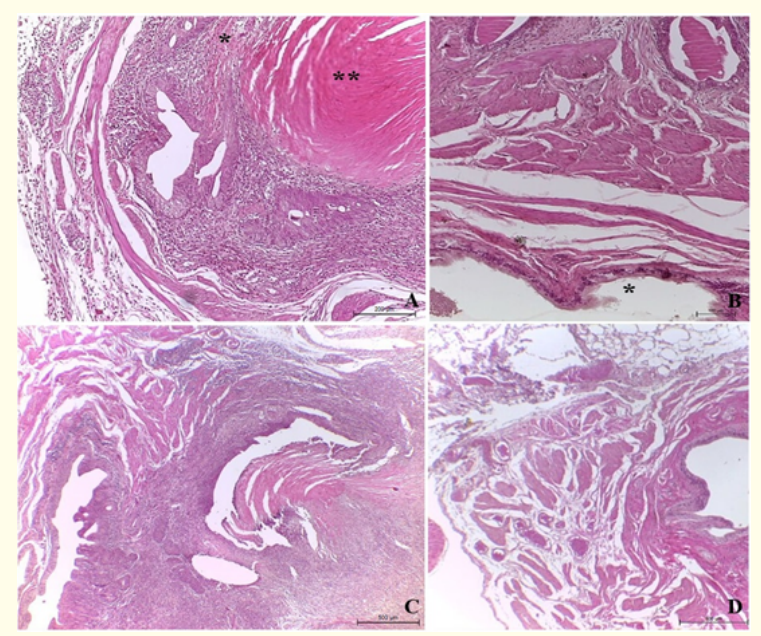

Figure 2: Rat bladder photomicrography after partial cystectomy surgery. A. T7 subgroup with intense inflammatory infiltrate around tunica albuginea implant and dense collagen (**), development of the muscular layer and initial urothelization $(*)$. HE, 10x. B. S7 subgroup showing continuous but disorganized urothelium (*) as well as the muscular layer and rare polymorphonuclear cells. HE, 10x. C. T14 subgroup with complete urothelization, moderate inflammatory infiltrate spreading over tunica albuginea xenograft. HE, 4x. D. S14 subgroup presenting complete urothelization and intense neovascularization. HE, 10x.

Since greater neovascularization was seen at 28 and 42 postoperative days, this alteration can be related to urinary deposits formation and local inflammation generated by friction. However, uroliths formation was equal in both $\mathrm{T}$ and $\mathrm{S}$ groups and neovascularization was greater in the T group, as well as Zhou., et al. [20] findings. 


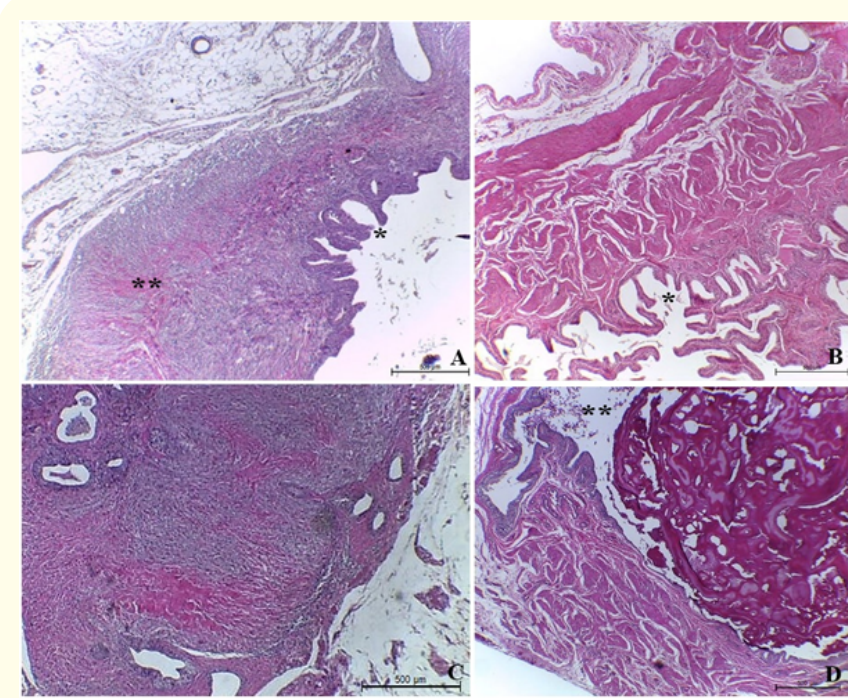

Figure 2: Rat bladder photomicrography after partial cystectomy surgery. A. T28 subgroup with complete urothelization $\left(^{*}\right)$ and intense inflammatory infiltrate involving residual tunica albuginea ${ }^{* *}$ ). HE, 4x. B. S28 subgroup showing urothelium (*) continuity and lamina propria development. HE, 4x. C. T42 subgroup presenting complete regeneration and inflammatory infiltrate with remnant tunica albuginea. HE, 4x. D. S42 subgroup showing complete regeneration, moderate inflammatory infiltrate and calculus in bladder lumen ${ }^{* *}$ ). HE, $4 x$.

The OTA availability, easy handling, upkeeping, simple surgical implantation technique, and inexpensiveness reinforce the importance of research in order to define its applicability in urinary vesicle repair surgery routine. In addition, OTA promoted early healing and integration to bladder tissue with no rejection signs in rats.

\section{Conclusion}

Ovine tunica albuginea graft showed successful results in reconstructing rats' bladder without rejection. It was proved to be an adequate biomaterial option in cystoplasty since it showed good integration to original tissue, induction of neovascularization, and bladder layers regeneration. Still, experiments of OTA graft in rats represented a valuable animal model to comparative research in other species. Our results supported and encouraged the application of OTA in further experimental and clinical trials to ascertain the best choice for bladder grafting in different species.

\section{Acknowledgements}

This study was supported by Coordenação de Aperfeiçoamento de Pessoal de Nível Superior (CAPES) of the Brazilian Ministry of Education.

\section{Conflict of Interest}

The authors declare that there is no conflict of interest.

\section{Bibliography}

1. Greca FH., et al. "Retalho de submucosa de intestino delgado autólogo para aumento da capacidade vesical da bexiga: estudo experimental em cães". Revista do Colégio Brasileiro de Cirurgiões 29 (2002): 294-299.

2. Zhang Y., et al. "Challenges in a larger bladder replacement with cell-seeded and unseeded small intestinal submucosa grafts in a subtotal cystectomy model". BJU International 98 (2006): 1100-1105.

3. Jack GS., et al. "Urinary bladder smooth muscle engineered from adipose stem cells and a three-dimensional synthetic composite". Biomaterials 30 (2009): 3259-3270.

4. Jin C., et al. "A Lipid-Nanosphere-Small MyoD Activating RNABladder Acellular Matrix Graft Scaffold [NP(saMyoD)/BAMG] Facilitates Rat Injured Bladder Muscle Repair and Regeneration [NP(saMyoD)/BAMG]". Frontiers in Pharmacology 11 (2020): 1-12.

5. Pope JC., et al. "The ontogeny of canine small intestinal submucosa regenerated bladder". The Journal of Urology 158 (1997): 1105-1110.

6. Voyti-Harbin SL., et al. "Identification of extractable growth factors from small intestinal submucosa”. Journal of Cellular Biochemistry 67 (1997): 478-491.

7. Portis AJ., et al. "Laparoscopic augmentation cystoplasty with different biodegradable grafts in an animal model". The Journal of Urology 164 (2000): 1405-1411.

8. Lin HK., et al. "Biomatrices for bladder reconstruction". Advanced Drug Delivery Reviews 82 (2015): 47-63.

9. Mathur RK., et al. "Tunica albuginea urethroplasty for anterior urethral strictures: A urethroscopic analysis". International Journal of Urology 16 (2009): 751-755.

10. Queiroz FF., et al. "Ensaio biomecânico da túnica albugínea bovina conservada em glicerina 98\% para utilização como membrana biológica”. Ciência Rural 42 (2012): 501-506.

11. Oliveira LL., et al. "Avaliação histológica da túnica albugínea bovina como biomaterial conservada em glicerina a 98\% e em glutaraldeído a 0,625\%". Revista Brasileira de Medicina Veterinária 37 (2015): 309-315. 
12. Canellas ACC., et al. "Emprego de Túnica albugínea heteróloga ovina como reforço de parede abdominal em ratos". Pesquisa Veterinária Brasileira 37 (2017): 1108-1112.

13. Moraes TA., et al. "Morpho-fuctional evaluation of porcine tunica albuginea as a graft for cystoplasty in rats". Arquivo Brasileiro de Medicina Veterinária e Zootecnia 69 (2017): 91169118.

14. Hsu GL., et al. "Anatomy and Strength of the Tunica Albuginea: Its Relevance to Penile Prosthesis Extrusion". The Journal of Urology 151 (1994): 1205-1208.

15. Junqueira LC. and Carneiro J. "Histologia Básica”. 13th edition. Rio de Janeiro: Guanabara Koogan (2017): 554.

16. Tolosa EMC., et al. "Manual de Técnicas Para Histologia Normal e Patológica”. 1 ed. São Paulo: Manole (2003): 331p.

17. Albrecht R., et al. "Aplicação de cola de fibrina autóloga e cola de N-Butil-cianoacrilato com implante de pericárdio suíno em cistoplastia experimental em coelhos (Oryctolagus cuniculus)". Revista Portuguesa de Ciências Veterinárias 110 (2015): 215-220.

18. Pokrywczynska M., et al. "Is the Poly (L-Lactide-co-Caprolactone) nanofibrous membrane suitable for urinary bladder regeneration?". PLOS ONE 9 (2014): e105295.

19. Iijima K., et al. "Transplantation of preserved human amniotic membrane for bladder augmentation in rats". Tissue Engineering 13 (2007): 513-524.

20. Zhou Z., et al. "Adipose-derived stem-cell-implanted poly(ecaprolactone)/chitosan scaffold improves bladder regeneration in a rat model". Regenerative Medicine 13 (2018): 331342.

21. Pinto Filho STL., et al. "Avaliações clínica, ecográfica e anatomofisiológica do alotransplante parcial de vesícula urinária com células-tronco mesenquimaisalogênicas derivadas do tecido adiposo em coelhos". Arquivo Brasileiro de Medicina Veterinária e Zootecnia 67 (2015): 1304-1312.

22. Wongsetthachai P., et al. "Urinary bladder wall substitution using autologous tunica vaginalis in male dogs". Research in Veterinary Sciences 90 (2011): 156-159.

23. Zhao Y., et al. "Time-dependent bladder tissue regeneration using bilayer bladder acellular matrix graft-silk fibroin scaffolds in a rat bladder augmentation model". Acta Biomaterialia 23 (2015): 91-102.
24. Kosan M., et al. "Tissue reactions of suture materials (polyglactine 910, chromed catgut and polydioxanone) on rat bladder wall and their role in bladder stone formation". Urological Research 36 (2008): 43-49.

25. Xia D., et al. "Immunomodulatory response of layered small intestinal submucosa in a rat bladder regeneration model". Journal of Biomedical Materials Research 107 (2019): 1960-1969.

26. Wang Y., et al. "Bioengineered bladder patches constructed from multilayered adipose-derived stem cell sheets for bladder regeneration". Acta Biomaterialia 85 (2019): 131-141.

\section{Assets from publication with us}

- Prompt Acknowledgement after receiving the article

- Thorough Double blinded peer review

- Rapid Publication

- Issue of Publication Certificate

- High visibility of your Published work

Website: www.actascientific.com/

Submit Article: www.actascientific.com/submission.php Email us: editor@actascientific.com

Contact us: +919182824667 